\title{
The Influence of Budgetary Participation, Work Experience, and Role Conflict on Managerial Performance with Motivation as Intervening Variable
}

\author{
Meutia Fadilah Mustika ${ }^{1}$, Alimuddin $^{2}$, and Aini Indrijawati ${ }^{3}$ \\ \{meutiafadilahm@gmail.com ${ }^{1}$, alimuddinfeb uh@gmail.com ${ }^{2}$, \\ ainiindrijawati@yahoo.com ${ }^{\overline{3}}$ \} \\ Universitas Pejuang Republik Indonesia ${ }^{1}$, Universitas Hasanuddin, Makassar, Indonesia ${ }^{2,3}$
}

\begin{abstract}
This study aims to analyze budget participation planning, work experience, and role conflict on managerial performance. This study has selected several lecturers from one of the private universities in South Sulawesi. The data collected were analyzed using path analysis. The results prove that budgetary participation is significantly positive for motivation, while work interactions and interactions are not significant on motivation. Furthermore, budgetary participation and role conflict significantly influence managerial performance. The work experience is not expected on managerial performance. The participation in budget planning and indirect work participation is greater than the direct comparison of the improvement in managerial performance. In the role conflict, the motivation is direct to managerial performance. These results indicate that indirect motivation participation in budget planning is significantly positive on managerial performance. Furthermore, indirect work experience through motivation for managerial performance. Finally, significant direct role conflict on managerial performance through motivation.
\end{abstract}

Keywords: Managerial performance, budget participation, work experience, role conflict, motivation, path analysis.

\section{Introduction}

Managerial performance is the performance of individual members of the organization in managerial activities, including coordination planning, supervision or supervision, staff selection, negotiation, and representation [1]. Performance appraisal is one of the key factors for developing an organization to be more effective and efficient. One of the things that can be used as a tool to assess the performance of an organization is the budget by controlling in terms of direction and control of individuals involved in the organization. Budgeting must be guided by the objectives, strategies, and main policies of the organization that have been set. Need to evaluate performance to measure the level of achievement of the plan set with the goals to be achieved. Thus the budgeting needs to be done so that organizational goals can be achieved. Participation in budgeting occurs when there are involvement and level of influence felt by individuals. In fact, the participation of lecturers or campus experts is very low in the budgeting process. According to Sukrino in Pikiran Rakyat Online (2014), the impact of fluctuating budgets on universities or colleges is due to the lack of participation from lecturers, so the budget tends to be of poor quality and full of interests. Weak lecturer participation in budgeting decision making weakens the commitment, 
satisfaction, and performance of lecturers. In addition, such a budget weakens the control and quality of higher education budgeting [2].

Improving the quality of service at the university is very necessary in order to compete with other universities so that employees should be required to have good work experience and have high professionalism. Skills or skills possessed to make it easier to do work that is his responsibility and is expected to improve performance at work. Skill or the ability of someone to carry out their duties and activities is obtained along with the working period in the occupied field. Therefore work experience is considered important in evaluating the performance of an organization.

One of the problems that often occur at universities or colleges, especially private universities, is the conflict between lecturer and stakeholders. Conflicts occur because professional workers have norms and value systems that clash with the norms, rules, and value systems that apply. Conflicts that often occur are role conflicts, i.e., conflicts that arise because of the multiple roles that must be undertaken by individuals/lecturers that have the potential to cause adverse impacts on the organization. Some empirical evidence shows that professional workers who work in bureaucratic organizational environments experience role conflict [3]. This is because, in general, role conflicts arise because of the existence of two different commands that are received simultaneously, and the execution of one command can lead to the neglect of the other command. According to Assegaf (2005), this conflict arises because, in addition to being a member of an organization, a professional employee is also a member of a profession governed by a code of ethics and professional performance standards, whereas as a member of the organization, he is obedient and is subject to the prevailing norms and regulations, and to hierarchical authority and supervision [4].

In addition to work experience, or participation in budgeting, there are other things that can affect performance, namely motivation. Motivation is the driving force in someone's heart to do or achieve a goal. Motivation not only affects budgeting participation and work experience, but also affects the occurrence of role conflicts in individual/college lecturers, with the motivation arising in a person to do something, and then the work can be done well. Conversely, if there is no underlying motivation for someone to do a job, then the possibility to do a job with a maximum is very minimal. Related to the role conflict itself, with a large motivation on one of the roles carried out by someone, then the individual will choose to carry out the orders of the role with the greater motivation that can cause problems in the organization.

\section{Literature Review}

\subsection{Goal-Setting Theory}

The goal-setting theory was developed in 1990 by Lock and Latham, who stated that the efforts made by individuals to achieve an individual's goals and commitments to his goals are important factors that influence individual behavior. Interest has two dimensions of content and intensity. The dimension of content refers to the object or desired outcome and is more directed at several external aspects. Intensity refers to several factors and the integrity of the goal-setting process, and the effort needed to set goals. Someone who wants to achieve their short-term and long-term goals, then goals will influence their behavior. 
The goal-setting theory states that individual behavior is governed by one's ideas (thoughts) and intentions. Targets can be seen as goals or levels of performance that individuals want to achieve. If an individual is committed to achieving his goals, then this will affect his actions and affect the consequences of performance. This theory also explains that setting goals that are difficult and measurable results will be able to improve work performance, followed by ability and work skills. The theory of goal setting is assumed that achieving optimal performance must be adjusted to individual and organizational goals.

\subsection{Budgeting Participation}

According to Robbinson (1982), in Putra (2013) states "participation in budgeting is a process in which individuals are involved in budgeting, then the individual is evaluated for performance and is rewarded based on budget targets." Based on these statements indicate that the role of budget participation is very important in increasing employee behavior and performance [5].

Participation in budgeting requires contributions from various parties. This statement is in accordance with the opinion of Anthony and Govindarajan (2005) in Dina (2014), which states that there are three approaches in budgeting, namely [6]:

a. Top-down approach

b. Approach from the bottom up

c. Combination approach between Top-Down and Bottom-Up or Participation approach.

Based on this approach implies that, if the preparation of the budget is only based on the wishes of superiors without accompanied by the participation of subordinates, it can cause difficulties for subordinates to meet their budget targets. The second approach implies that if the preparation of the budget is only based on the wishes of subordinates can cause a lack of motivation for subordinates to meet organizational targets. Whereas what is meant by the participation approach is a combination of the Top-Down approach and the Bottom-Up approach. This approach is considered as the most effective approach because it requires cooperation and interaction between superiors and subordinates in preparing the budget. This is considered to produce a budget that is truly appropriate because it has the support of both parties, so it is expected that there is a strong commitment to implementation. Budgeting participation is a budgeting activity that involves every level of manager. In higher education, the budget is prepared based on performance, namely the preparation of a budget based on performance planning, which consists of programs and activities to be carried out as well as performance indicators to be achieved.

\subsection{Work experience}

Work experience shows the ability or skills possessed by someone. Someone who has work experience in a field or in a particular field will be easier to understand the work compared to people who do not have work experience. Thus, work experience means the level of mastery of one's knowledge and skills at work, which can be measured from the knowledge of the skills possessed and the years of service. In fact, the longer the employee works, then it will be more and more experience of these employees. Conversely, the shorter the working period they have, the less experience gained. The limited work experience causes the level of expertise and skills possessed will be increasingly low. 
Through one's work experience consciously or not, that person will have technical skills, as well as skills in dealing with his work. Work experience and employee training will make it easier to complete the work that is charged. Thus, work experience is very important, because by gaining work experience the assigned tasks can be done well so that it affects managerial performance. The statement explains how work experience relates to managerial performance.

\subsection{Role Conflict}

According to Robbins and Judge, translated by Saraswati and Sirait (2015: 183), role conflict is a situation in which individuals are faced with different role expectations [7]. According to Kreitner and Kinicki, translated by the Alchemist Language Bureau (2014: 15), role conflict occurs when members of different role orders expect different things from the recipient [8]. Handoko (2012: 349) said that role conflict in an individual is something that occurs when an individual faces uncertainty about the work he expects to carry out, when various job requests conflict with each other or if the individual is expected to do more than his ability. That is, role conflict arises because there are two different commands that are received simultaneously, and one of them is contrary to what is expected by the recipient of the role [9].

Conflicts role is defined as the pressure of the pressure groups of two or more simultaneously so that adherence to one group will lead to difficulty or impossibility to comply with the other [10]. According to Abernethy and Stoelwinder (1995), the level of role is influenced by how far professionals want to maintain their professional attitude in the company and to what extent the prevailing control environment in the company threatens the autonomy of these professionals [11]. Role conflict has a negative impact on employee behavior such as the emergence of work tension, increased job turnover (the number of workers moving), decreased job satisfaction, decreased commitment to the organization, and decreased overall performance [12]. De Luis Carnicer et al. (2005) define role conflict as the simultaneous condition of two or more forms of pressure on the workplace, where the fulfillment of one role makes it more difficult to find other roles. That is, role conflict occurs when someone carries out one particular role and feels difficulty in fulfilling his other roles. This conflict can be a trigger in the destruction of the organization through the creation of a dividing wall between coworkers, poor performance, and even resignation or dismissal [13].

\subsection{Motivation}

According to Herzberg and Frederick cited by Luthans (1992), which are classified as motivational factors include achievement, recognition or appreciation, work itself, responsibility, and development. Motivation originating from outside the self, which also determines a person's behavior in a person's life, known as hygiene factors [14]. According to Herzberg cited by Luthans (1992), classified as extrinsic motivations are policy and administration, interpersonal relations, working conditions, and wages [14].

The basic principle of motivation is the level of ability and individual motivation that can be said that the performance of a person or group is based on the ability and motivation they have. According to these principles, no task can be carried out properly without being supported by the ability to carry it out. The ability is an individual or group talent to carry out tasks related to the goal, but the ability is not sufficient to guarantee the achievement of good performance; therefore one must have the desire (motivation) to achieve the best performance. Motivation is a motivator from someone's heart to do or achieve something. In other words, 
motivation is a process for achieving a goal. With motivation, it means that someone has the power to achieve success or dreams in life.

\subsection{Managerial Performance}

Januarita (2014) states that managerial performance is the performance of individual members of the organization in managerial activities, including: planning, coordination, supervision or supervision, staff selection, negotiation, and representation. For an organization, managerial performance can be a measure of the extent to which managers carry out management functions [1]. From the above understanding, it can be concluded that managerial performance is the result achieved by individuals who have authority over all managerial activities, such as planning activities, organizing activities, directing activities, and control activities in which all of these activities are used for the decision making process and the decision is made a tool strategy for achieving the goals of an organization.

1. Planning for which is the action that is based on facts and assumptions that will come in order to achieve the desired objectives. Planning aims to provide guidelines and procedures for the implementation of objectives, policies, procedures, budgeting, and work programs so that they are carried out in accordance with established targets.

2. The investigation, namely the efforts made to collect and prepare the information in report form. Record and analyze the work to be able to measure the results of its implementation.

3. Coordination is the process of collaborating with other parts of an organization through the exchange of information associated with adjusting work programs.

4. Evaluating is an assessment made by the managerial of the plans that have been made and are intended to assess employees and records of work results so that the results of the assessment can be taken the necessary decisions.

5. Supervision is an assessment to get confidence that planning, coordinating, compiling, and directing have been running effectively.

6. Election Staff, which is often referred to as the preparation of the personnel management functions with regard to recruitment, withdrawal, placement, giving exercise to employees, promote employees, and transferring to the employee who is certainly attention to an employee's skills and needs of an organization.

7. Negotiations, in this case, with regard to decision-making, either in one part or as a whole in an organization with align between the needs of the organization with the special needs of employees especially in the budgeting process and the achievement of budget targets.

8. Representative, which convey information about the vision, mission and activities of an organization by attending community events and approaches to the public to promote the general objectives of an organization.

\section{Research Methods}

This study uses quantitative research methods to obtain empirical evidence about the Effect of Budgeting Participation, Work Experience, and Role Conflict on Managerial Performance with Motivation as an Intervening variable in private universities in Makassar. The type of data in this study is Primary Data. The data source comes from the answers to the 
questionnaire distributed to respondents. Data collection is done by submitting a questionnaire to respondents with a questionnaire guide containing questions based on the proposed indicators. Data collection is carried out using the direct distribution method (i.e. the direct distribution method), which is to go to the respondents directly to be sent or collected the questionnaire. Respondents responded to fill in the form of Likert scale in the number of categories containing five levels.

The number of participants was 50 people, the number of employees was 50 people, and the number of staff was 75 people. The sample selection in this study was conducted by purposive sampling. The research samples in this study are officials who have structural positions and officials who are related to the budget. The conceptual framework in this study can be seen in Figure 1 as follows.

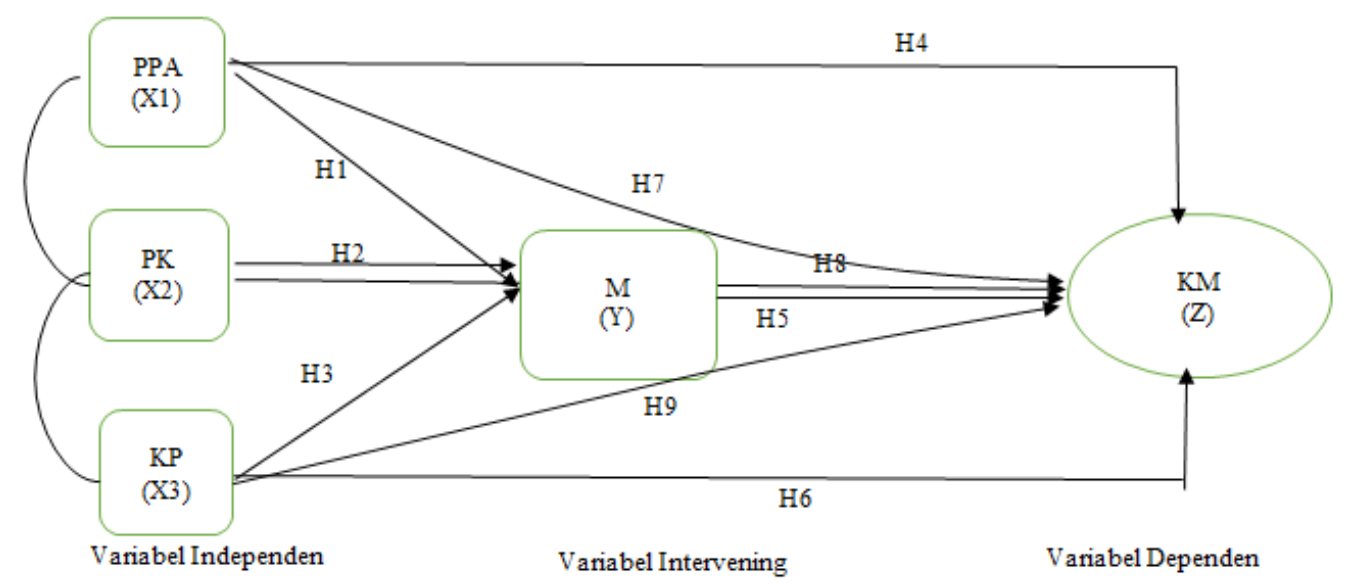

Fig. 1. Research Conceptual Framework

\section{Results}

\subsection{Line I Coefficient}

This section examines the amount of contribution (contribution) shown by the path coefficient of the causal relationship between variables $\mathrm{X} 1, \mathrm{X} 2$, and $\mathrm{X} 3$ to the variable $\mathrm{Y}$. Based on the results of the regression model of model 1 in table 1 , it can be seen that the significance value of the three variables is $\mathrm{X} 1=0.004, \mathrm{X} 2=0.234$, and $\mathrm{X} 3=-0.176$. These results provide conclusions brought to the regression model 1, the budgeting participation variables that have a significant effect on $\mathrm{Z}$.

Table 2 shows the R-value of 0.368 , which means that the correlation between managerial performance and budget participation, work experience, and role conflict is $36.8 \%$, while the remaining $63.2 \%$ was influenced by other variables not examined in this study. Meanwhile, for the value of e $1=0.7949$. Thus the path diagram for structure model 1 is as follows: 


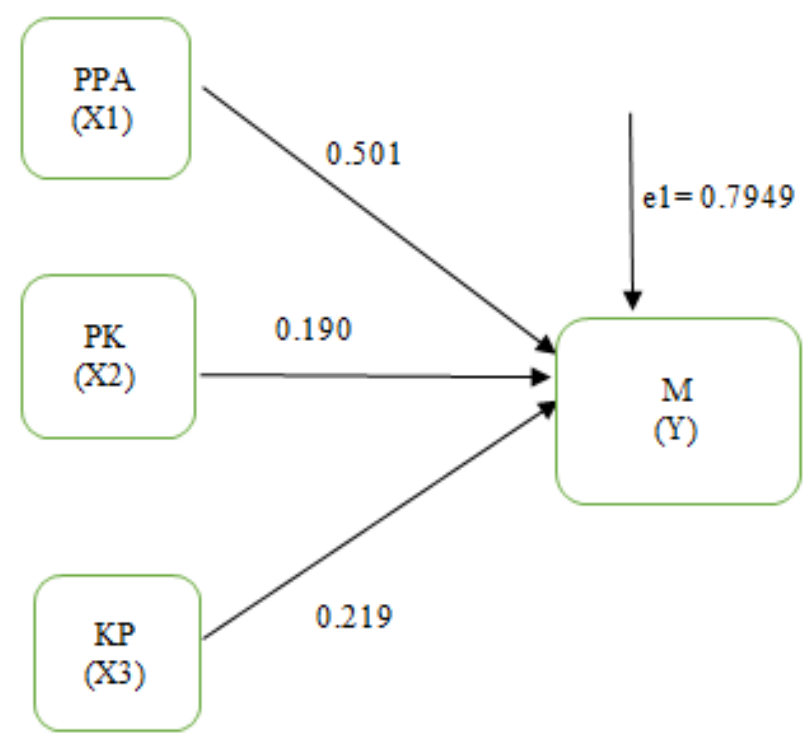

Fig. 2. Structure diagram path model I

Table 1. Statistical Test Results

\begin{tabular}{|c|c|c|c|c|c|c|}
\hline \multirow[b]{2}{*}{ Model } & & \multicolumn{2}{|c|}{$\begin{array}{l}\text { Unstandardized } \\
\text { Coefficients }\end{array}$} & \multirow{2}{*}{$\begin{array}{c}\begin{array}{c}\text { Standardized } \\
\text { Coefficients }\end{array} \\
\text { Beta }\end{array}$} & \multirow[b]{2}{*}{$\mathrm{t}$} & \multirow[b]{2}{*}{ Sig. } \\
\hline & & $\mathrm{B}$ & Std. Error & & & \\
\hline \multirow[t]{4}{*}{1} & (Constant) & 154.494 & 30.762 & & 5.022 & .000 \\
\hline & Budget Participation & 1.413 & .443 & .501 & 3.186 & .004 \\
\hline & Work Experience & 1.431 & 1.176 & .190 & 1.217 & .234 \\
\hline & Role Conflict & -.806 & .579 & -.219 & -1.392 & .176 \\
\hline
\end{tabular}

a. Dependent Variable: Motivation

Table 2. Determination Coefficient Test Results

\begin{tabular}{lccrr}
\hline Model & R & R Square & Adjusted R Square & $\begin{array}{c}\text { Std. An error of } \\
\text { the Estimate }\end{array}$ \\
\hline 1 & $.606^{\mathrm{a}}$ & .368 & .295 & 13.34225 \\
\hline $\begin{array}{l}\text { a. Predictors: (Constant), Role Conflict, Work Experience, Budget } \\
\text { Participation }\end{array}$
\end{tabular}




\subsection{Line Model II Coefficient}

Because this research uses path analysis, so it needs to be done twice regression. This section is used to test the magnitude of the contribution (contribution) shown by the path coefficient on each path diagram of the causal relationship between variables X1, X2, and X3 on $\mathrm{Y}$ and its impact on $\mathrm{Z}$ with the aim to determine the direct and indirect effect of a set of independent variables on the variable dependent. Based on table 3 shows the R-value of 0.52 , this means that the influence of budgeting participation, work experience, role conflict, and motivation on performance is $52 \%$, and the remaining $48 \%$ is a contribution from other variables not examined. The value of $\mathrm{e} 2=0.6928$. Thus obtained the path model II structural model as follows:

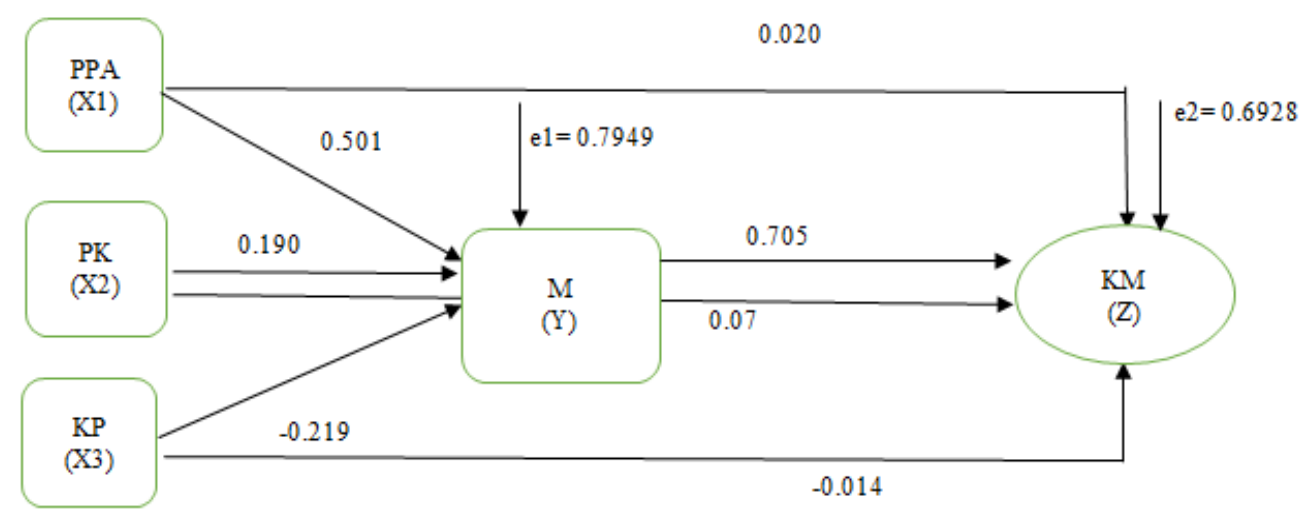

Fig. 3. Structure Diagram Path Model II

Hypothesis Test Results

1. Analysis of the Effect of $\mathrm{X} 1$ on $\mathrm{Y}$ : from the results of the analysis above, obtained a significance value of $\mathrm{X} 1$ of $0.004>0.05$. So it can be concluded that there is a significant direct effect on budgetary participation on motivation.

2. Analysis of the effect of $\mathrm{X} 2$ on $\mathrm{Y}$ : from the results of the analysis results, it was obtained that the significance value of $\mathrm{X} 2$ was $0.234>0.05$. So it can be concluded that there is influence.

3. Analysis of the Effect of $\mathrm{X} 3$ on $\mathrm{Y}$ : From the results of the analysis of the data obtained, the significance value of $\mathrm{X} 3$ was $0.176<0.05$. So it can be concluded that role conflict does not directly influence motivation.

4. Analysis of the Effect of $\mathrm{X} 1$ on $\mathrm{Z}$ : from the results of the analysis above, obtained a significance value of $\mathrm{X} 1$ of $0.020<0.05$. So it can be concluded that there is a significant direct effect on budgetary participation on managerial performance.

5. Analysis of the Effect of $\mathrm{X} 2$ on $\mathrm{Z}$ : from the results of the analysis above, obtained a significance value of $X 2$ of $0.07>0.05$. So it can be concluded that there is no significant direct effect of work experience on managerial performance. 
6. Analysis of the Effect of $\mathrm{X} 3$ on $\mathrm{Z}$ : from the results of the analysis above, obtained a significance value of $\mathrm{X} 3$ of $-0.014<0.05$. So it can be concluded that there is a significant direct effect of role conflict on managerial performance.

7. Analysis of the Effect of $\mathrm{X} 1$ through $\mathrm{Y}$ on $\mathrm{Z}$ : note the direct effect given $\mathrm{X} 1$ on $\mathrm{Z}$ is 0.020 , whereas the indirect effect of $\mathrm{X} 1$ through $\mathrm{Y}$ on $\mathrm{Z}$ is 0.353 . Then the total effect given $\mathrm{X} 1$ on $\mathrm{Z}$ is $0.020+0.353=0.373$. Based on the results of these calculations, it is known that the value of the indirect effect is greater than the value of the direct effect. These results indicate that indirect participation in budgeting through motivation has a significant influence on managerial performance.

8. Analysis of the Effect of $\mathrm{X} 2$ through $\mathrm{Y}$ on $\mathrm{Z}$ : it is known that the direct effect of $\mathrm{X} 2$ on $\mathrm{Z}$ is 0.07 , whereas the indirect effect of $\mathrm{X} 2$ through $\mathrm{Y}$ on $\mathrm{Z}$ is 0.133 . Then the total effect given $\mathrm{X} 2$ on $\mathrm{Z}$ is $0.07+0.133=0.203$. Based on the results of these calculations, it is known that the value of the indirect effect is greater than the value of the direct effect. These results indicate that indirect work experience, through motivation, has a significant influence on managerial performance.

9. Analysis of the Effect of $X 3$ through $Y$ on $Z$ : it is known that the direct effect given $X 3$ on $\mathrm{Z}$ is -0.014 whereas, the indirect effect of $\mathrm{X} 3$ through $\mathrm{Y}$ on $\mathrm{Z}$ is -0.158 . Then the total effect given $\mathrm{X} 3$ on $\mathrm{Z}$ is $(-0,014)+(-0,158)=-0,172$. Based on the calculation results, it is known that the value of the direct effect is greater than the value of the indirect effect. These results indicate that direct role conflict, through motivation, has a significant influence on managerial performance.

\section{Discussion}

Based on the analysis and testing of the above hypotheses, it is known that budgetary participation, work experience, and role conflict with their influence on motivation, only the budget participation variable has a significant positive effect on motivation. So, it can be concluded that the results of this study accept hypothesis one, and reject hypotheses two and three.

Based on the results of data analysis and hypothesis testing above, it is known that budgetary participation has a significant positive effect on managerial performance. This means that the four hypotheses are accepted, and the null hypothesis is rejected. This is because the budget at private tertiary institutions is structured by involving management from the lower to upper levels so that participation is more maximal. In contrast to budgeting in state universities, usually, the budget in state universities has been allocated by the government, therefore, in this case, the participation of managers becomes ineffective because budget allocations have been provided even though sometimes not fully in accordance with the needs or plans that have been made.

From the results of the hypothesis analysis above, it is known that the work experience variable does not significantly influence managerial performance. This means that this research rejects hypothesis five, which states that work experience directly influences managerial performance. This is because, in this organization, most of the lecturers who have structural positions are those who, from the beginning, had a large share in the organization and have held their positions for several periods. In addition, in this tertiary institution, 
training for improving the quality of work still lacks so it does not greatly affect managerial performance.

Furthermore, from the results of data analysis and hypothesis testing above, it is known that role conflict has a significant negative effect on performance, so it can be concluded the results of this study accept the sixth hypothesis, which states that role conflict influences managerial performance. This is because the number of lecturers or structural officials who have more than one role or position in this organization so that the possibility of role conflict is very large.

In the results of the analysis and testing of hypothesis seven, which assesses the effect of budgetary participation on managerial performance, motivation is considered capable of acting as an intervening variable. This is because there is a significant relationship between the independent variable budgeting participation with the mediator variable motivational and motivational mediator variables significantly influence the dependent variable, in this case, managerial performance. Thus hypothesis seven are accepted, with the indirect effect of the motivational variable being greater than the direct effect.

Furthermore, based on the results of the analysis and testing of hypotheses, it is known that there is an indirect effect between budgeting participation on managerial performance through motivation. Based on the test results, it is proven that it is not able to influence the relationship between work experience and managerial performance. Thus, the motivation variable here cannot be said to be an intervening variable because the relationship between the independent variables of work experience is not significant with the mediator variable, which is motivation.

Finally, in relation to motivation as a mediator, role conflict also has a direct effect on managerial performance through motivation. Based on this, this result means that hypothesis nine is accepted, and the null hypothesis is rejected. However, motivation in the interaction of role conflict on managerial performance is only as a mediator, not as an intervening variable. Because role conflict can occur due to two different functions where the two functions have two different objectives, so, that role conflict will arise if one of the goals of a role, both as a lecturer and manager is not reached to the maximum because one of the roles does not work as it should. Role conflict arises because there are two or more pressures that appear simultaneously aimed at someone so that the role bearer tends to choose to carry out the role in accordance with the amount of motivation he has.

\section{Conclusion}

Based on the results of research conducted to determine the effect of budgeting participation, work experience, and role conflict on managerial performance with motivation as an intervening variable is as follows: First, budgetary participation has a significant influence on managerial performance. This is because, in private tertiary institutions, the budget is prepared by involving managers from low to top-level managers. Second, both motivations are intervening variables because of the interaction between budgeting participation in managerial performance and being moderated by motivation. This is because the independent variable budgeting participation affects the mediator variable motivation, and motivation affects the dependent variable managerial performance. The analysis shows that budgetary participation has a significant influence indirectly through motivation on managerial performance. 
Third, work experience does not have a significant effect on managerial performance. This is because, in the organization, most of the lecturers who have structural positions are those who, from the beginning, have a big hand in the organization and have occupied their positions for several periods. Fourth, the motivation variable does not act as an intervening variable in effect between work experiences on managerial performance. These results indicate motivation does not affect performance in terms of improving work experience. This is because, in this organization, training programs to improve the quality of work of employees are still lacking. The analysis shows that work experience indirectly influences managerial performance through motivation.

Fifth, role conflict has a significant negative effect on managerial performance. Role conflict, which is one of the most common problems in tertiary institutions, causes this variable to be negative. This is because most structural officials in private tertiary institutions, especially these organizations, carry more than one role, both as lecturers and as employees. Sixth, motivation acts as a mediator variable because of the interaction between role conflict and managerial performance. This is because the relationship of role conflict to motivation is not significant, and only the relationship of motivation that significantly influences managerial performance. The analysis shows that role conflict directly through motivation influences managerial performance.

The author is aware of the limitations of this study so that this limitation might affect the achievement of the desired results. Some limitations in this study are the sample selection of only one private tertiary institution in the city of Makassar, so the results of this study may not affect the overall validity of the results. In addition, this study uses a questionnaire method without being equipped with interviews so that the possibility of the validity of results is less efficient. Respondents' answers do not necessarily reflect the real situation.

\section{References}

[1] Januarita, Sintia, and Baihaqi.: Pengaruh Sistem Pengendalian Akuntansi Dan Komitmen Organisasi Terhadap Kinerja Manajerial (Studi Empiris Pada Perusahaan leasing di Kota Bengkulu). Undergraduated thesis. Universitas Bengkulu (2014).

[2] Pikiran Rakyat Online, "Fluctuating Budgets on Universities."

[3] Comerford S. E. and Abernethy M. A.: Budgeting and the management of role conflict in hospitals. Behavioral Research in Accounting. vol. 11, pp. 93 (1999).

[4] Assegaf and Umar Y.: Pengaruh Konflik Peran dan Stres Kerja Terhadap Komitmen Organisasi. Jurnal Akuntansi \& Bisnis. vol. 5, no. 2, (2005).

[5] Putra, A.: Pengaruh Pelatihan Dan Motivasi Kerja Terhadap Kinerja Karyawan. Pembuat Kerajinan Tangan Gerabah (2013).

[6] Ariyanti. D.: Pengaruh Kompensasi, Motivasi, Dan Keahlian Terhadap Kinerja Karyawan (Survei Terhadap PT. PLN (Persero) Di Kecamatan Sumberlawang). Universitas Muhammadiyah Surakarta (2014).

[7] Stephen R. P. and Timothy J. A.: Perilaku Organisasi, 16th ed. Salemba Empat: Jakarta (2015).

[8] Kreitner and Kinicki.: Measurement of Employee Job Satisfaction. PT.Gramedia: Jakarta (2014).

[9] Handoko T. H.: Manajemen. BPPE Yogyakarta: Yogyakarta (2012).

[10] Wolfe D. M and Snoek J. D.: A Study of Tensions and Adjustment Under Role Conflict 1," Journal of Social Issues. vol. 18, no. 3, pp. 102-121 (1962).

[11] Abernethy. M. A and Stoelwinder. J. U.: The role of professional control in the management of complex organizations. Accounting, organizations and society. vol. 20, no. 1, pp. 1-17 (1995).

[12] Jackson. S. E and Schuler. R. S.: A meta-analysis and conceptual critique of research on role ambiguity and role conflict in work settings. Organizational behavior and human decision 
processes. vol. 36, no. 1, pp. 16-78, (1985).

[13] De Luis Carnicer. M. P, Sánchez.A. M, Pérez. M. P, and Jiménez. M. J. V.: Work-family conflict in a southern European country. Journal of Managerial Psychology. vol. 19, no. 5, pp. 446-489, (2004).

[14] Herzberg. F, Mausner. B, and Snyderman. B. B.: The Motivation to Work, John Wiley \& Sons. Inc., New York. vol. 195, (1959). 